\title{
Review \\ The Value of a Complete Blood Count (CBC) for Sepsis Diagnosis and Prognosis
}

\author{
Luisa Agnello ${ }^{1}$, Rosaria Vincenza Giglio ${ }^{1}$, Giulia Bivona ${ }^{1}\left(\mathbb{D}\right.$, Concetta Scazzone ${ }^{1}$, Caterina Maria Gambino ${ }^{1,2}$,

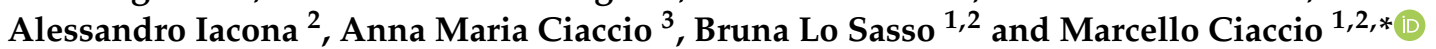 \\ 1 Department of Biomedicine, Neurosciences and Advanced Diagnostics, Institute of Clinical Biochemistry, \\ Clinical Molecular Medicine and Clinical Laboratory Medicine, University of Palermo, 90127 Palermo, Italy; \\ luisa.agnello@unipa.it (L.A.); rosaria.vincenza.giglio@alice.it (R.V.G.); giulia.bivona@unipa.it (G.B.); \\ concetta.scazzone@unipa.it (C.S.); cmgambino@libero.it (C.M.G.); bruna.losasso@unipa.it (B.L.S.) \\ 2 Department of Laboratory Medicine, University Hospital "P. Giaccone", 90127 Palermo, Italy; \\ alessandro.iacona84@gmail.com \\ 3 Unit of Clinical Biochemistry, University of Palermo, 90127 Palermo, Italy; annamaria.ciaccio@unipa.it \\ * Correspondence: marcello.ciaccio@unipa.it
}

Citation: Agnello, L.; Giglio, R.V.; Bivona, G.; Scazzone, C.; Gambino, C.M.; Iacona, A.; Ciaccio, A.M.; Lo Sasso, B.; Ciaccio, M. The Value of a Complete Blood Count (CBC) for Sepsis Diagnosis and Prognosis. Diagnostics 2021, 11, 1881. https:// doi.org/10.3390/diagnostics11101881

Academic Editor: Raul Colodner

Received: 30 August 2021

Accepted: 10 October 2021

Published: 12 October 2021

Publisher's Note: MDPI stays neutral with regard to jurisdictional claims in published maps and institutional affiliations.

Copyright: () 2021 by the authors. Licensee MDPI, Basel, Switzerland. This article is an open access article distributed under the terms and conditions of the Creative Commons Attribution (CC BY) license (https:// creativecommons.org/licenses/by/ $4.0 /)$.

\begin{abstract}
Sepsis represents an important global health burden due to its high mortality and morbidity. The rapid detection of sepsis is crucial in order to prevent adverse outcomes and reduce mortality. However, the diagnosis of sepsis is still challenging and many efforts have been made to identify reliable biomarkers. Unfortunately, many investigated biomarkers have several limitations that do not support their introduction in clinical practice, such as moderate diagnostic and prognostic accuracy, long turn-around time, and high-costs. Complete blood count represents instead a precious test that provides a wealth of information on individual health status. It can guide clinicians to early-identify patients at high risk of developing sepsis and to predict adverse outcomes. It has several advantages, being cheap, easy-to-perform, and available in all wards, from the emergency department to the intensive care unit. Noteworthy, it represents a first-level test and an alteration of its parameters must always be considered within the clinical context, and the eventual suspect of sepsis must be confirmed by more specific investigations. In this review, we describe the usefulness of basic and new complete blood count parameters as diagnostic and prognostic biomarkers of sepsis.
\end{abstract}

Keywords: biomarker; sepsis; CBC; CPD; thrombocytopenia; anemia; lymphocytes; neutrophils; monocytes; RBC

\section{Introduction}

Sepsis is a highly complex disease caused by the dysregulation of the host response to infection that leads to an uncontrolled inflammatory response followed by immunosuppression. It occurs as a complication of infections acquired both in the community and in healthcare settings, especially in intensive care units (ICU) [1], where it represents the most common cause of death, accounting for more than $50 \%$ of ICU mortality [2]. Overall, sepsis is considered a global health burden, with an important economic impact [3]. Thus, the rapid detection of sepsis is crucial in order to prevent adverse outcomes and reduce mortality by promptly starting the treatment before the occurrence of irreversible damage. It has been estimated that each hour of treatment delay is associated with a $7-10 \%$ increase in sepsis-related mortality [4]. However, the early diagnosis of sepsis is still challenging today because it is characterized by non-specific specific signs and symptoms. Thus, many efforts have been made to identify a reliable biomarker for screening patients at high risk of sepsis. Among all investigated sepsis biomarkers [5-8], parameters belonging to the complete blood count (CBC) could represent precious tools. Indeed, CBC has several advantages: (i) it represents the first-line laboratory test most commonly ordered in all clinical settings, from the emergency department (ED) to the ICU; (ii) clinicians routinely 
request $\mathrm{CBC}$ as part of the management of patients; (iii) it is easy to perform; (iv) it is cheap; (v) it has a fast turn-around time (TAT); (vi) it is available in all health facilities.

The aim of this review is to highlight the usefulness of CBC parameters for sepsis diagnosis and prognosis by putting together published literature on the subject matter. Specifically, we performed literature research on PubMed by combining the term "sepsis" and all terms related to the CBC parameters. We excluded articles written in other languages than English and those not related to sepsis.

\section{Sepsis Definition and Pathogenesis}

Sepsis has a long history dating back to over 2700 years ago when it was first mentioned in the ancient Greek poems of Homer. Since then, the definition of sepsis has shifted over time (Figure 1). Originally sepsis was thought to be an internal rotting or decaying due to the smell of patients affected [9]. The development of medical hygiene and the germ theory in the late 1800s modified the concept of sepsis from internal decay to originating from a harmful microorganism. In 1913, William Osler noted "except on few occasions, the patient appears to die from the body's response to infection rather than from it" [10]. The next year, Hugo Schottmüller created the basis for the modern definition of sepsis: "Sepsis is present if a focus has developed from which pathogenic bacteria, constantly or periodically, invade the bloodstream in such a way that this causes subjective and objective symptoms" [11]. However, over the course of the twentieth century, there emerged a need for an accurate and internationally recognized definition of sepsis. In 1992, the consensus conference of the Society of Critical Care Medicine and the American College of Chest Physicians, also known as Sepsis-1 conference, defined sepsis as infection-induced systemic inflammatory response syndrome (SIRS) [12]. Such definition was updated in 2002 by Sepsis- 2 conference [13]. After two decades, in 2016, the Sepsis-3 conference revolutionized the definition of sepsis by removing the concept of SIRS and describing it as "a life-threatening organ dysfunction resulting from infection" [14]. In other words, sepsis is caused by a deregulated response to a pathogen.

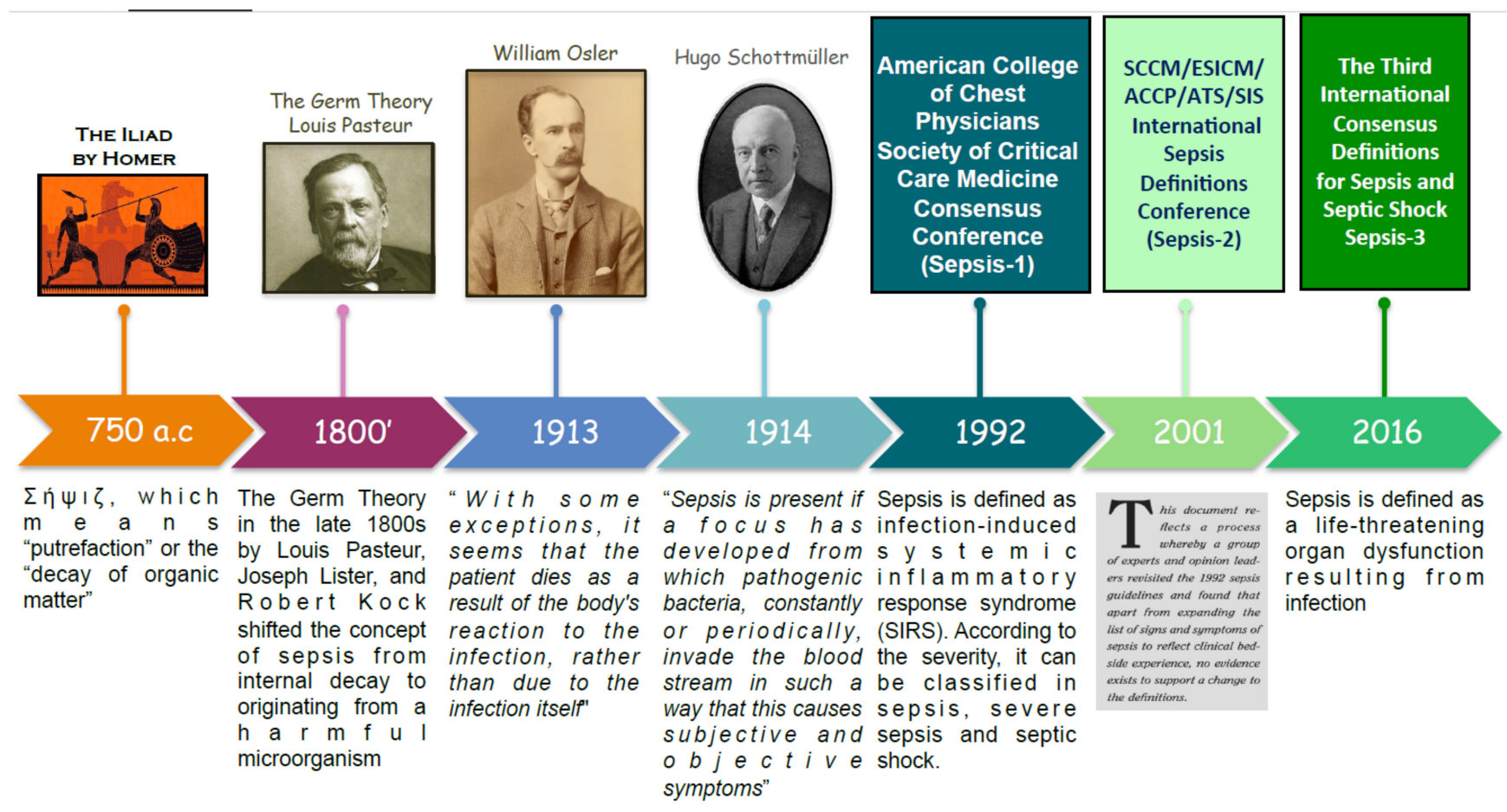

Figure 1. Timeline of the evolution of the sepsis definition.

Sepsis is a highly heterogeneous disease both in terms of etiology and pathogenesis [15]. Gram-negative bacteria are the most frequent pathogen causing sepsis, followed 
by gram-positive. Also, parasites and fungi can cause sepsis but to a lesser extent than bacteria. Notably, in about one-third of patients, the causative agent is not detectable.

The pathogenesis of sepsis can be ideally divided into two phases. An initial phase characterised by an intense inflammatory response to infection leading to the release of proinflammatory cytokines. Most patients $(\approx 60 \%)$ recover, while $30 \%$ transit to the late phase, characterised by immunosuppression [16]. In this scenario, the immune response, which consists of the innate and adaptive systems, has a key role. The innate immune system represents the first line of defence against pathogens. It is not specific and acts rapidly to fight infection. Eosinophil, basophil, and phagocytic cells, including macrophages and neutrophils, are components of the innate immune system. The adaptive immune system, consisting of lymphocytes $\mathrm{T}$ and $\mathrm{B}$, involves antigen-specific response, which is specific for the pathogen and regulated by crosstalk with innate immune cells. The adaptive immune response is important for confining the inflammation and tissue damage after infection and for returning immune homoeostasis.

During sepsis, pathogen-associated molecular patterns (PAMP) and danger-associated molecular patterns (DAMPs) induce the activation of innate immune cells, which release pro-inflammatory cytokines, leading to a robust inflammatory response characterized by the so-called "cytokine storm". The excessive inflammatory response could induce cell and tissue damage, leading to multi-organ dysfunction. Additionally, during sepsis, the adaptive immune response is deregulated, leading to immune suppression, which promotes secondary infections.

\section{Basic Complete Blood Count}

The $\mathrm{CBC}$ is the most common and easy-to-perform laboratory test, which provides a wealth of information on individual health status. The appropriate interpretation of this test is pivotal for the early detection of several clinical conditions, which should be further investigated by laboratory and clinical analysis.

The CBC parameters can be grouped into three categories: (i) white blood cells (WBC), (ii) red blood cells (RBC), (iii) platelets. In this section, we describe the parameters included in a basic $\mathrm{CBC}$, which can be provided by any hematological analyzer.

\subsection{White Blood Cells}

White blood cells, also known as leukocytes, are a heterogeneous population including lymphocytes, monocytes, and granulocytes, consisting of neutrophils, eosinophils, and basophils. It can be expressed as a percentage or as an absolute value. The WBC absolute value has clinical significance and is more informative than the relative one (percentage) because it indicates the medullary response to inflammatory stimuli. The relative value is helpful for evaluating which WBC population is mainly involved in the inflammatory process, allowing an etiological diagnosis.

Commonly, the increase of total WBC count is indicative of inflammation and infection. However, it can be altered in several clinical conditions, such as hemopathy, and in inflammatory non-infective disorders, such as rheumatoid arthritis, lupus, and malignancy $[17,18]$. Additionally, WBC count could be normal or even decreased in some cases of sepsis. Thus, total WBC has a poor specificity, which limits its usefulness as a biomarker of sepsis [14].

\subsubsection{Lymphocytes}

Lymphocytes are key components of the adaptive immune response. They make up approximately $20-40 \%$ of the total leukocyte count.

A hallmark of sepsis is the simultaneous presence of pro-inflammatory and immunosuppressive alterations [19]. The latter are characterized by the early massive depletion of lymphocytes due to apoptosis. Studies on mice and humans revealed that sepsisinduced apoptosis is driven either by extrinsic or intrinsic pathways [20,21]. Additionally, post-mortem studies on patients with septic shock showed that apoptosis occurs in both 
circulating cells and in solid organs [22]. Overall, sepsis-induced apoptosis leads to lymphocytopenia.

Several authors showed that lymphocyte count decreases in the early phase of sepsis and that it is associated with poor outcomes [23-26]. Drewry et al. showed that persistent lymphocytopenia, defined as an absolute lymphocyte count $\leq 0.6$ cells $/ \mu \mathrm{L} \times 103$, on the fourth day after sepsis diagnosis, is associated with an increased risk of 28-day mortality [27]. Similarly, Chung et al. showed that severe basal lymphopenia is associated with an increased risk of death by day 28 in patients with septic shock admitted to ICU [28].

Also, Sheikh Motahar Vahedi et al. found that lymphocytopenia is a predictor of 28-day mortality in patients with sepsis admitted to the ED [29]. Finally, Hohlstein et al. showed that lymphocytopenia at ICU admission is associated with increased mortality [30].

Overall, literature evidence suggests that lymphocytopenia could be an indicator of increased risk of mortality in patients with sepsis.

\subsubsection{Monocytes}

Monocytes represent the first line of defense against invading pathogens. They are activated by pattern recognition receptors (PRRs) and sepsis-associated hypoxia [31]. Monocytes control both the innate and adaptive immune responses to pathogens by different mechanisms, including phagocytosis; the release of reactive oxygen species, cytokines, and chemokines; the recruiting of neutrophils; antigen presentation; and the activation of lymphocytes [32].

Overall, monocytes can be classified into three different sub-population based on the different expression of a co-receptor to lipopolysaccharide (LPS), CD14, and CD16 receptor: classical (CD14+++CD16-), intermediate (CD14++ CD16+), and non-classical (CD14+ CD16++) [33], which present different morphological, functional, and phenotypical characteristics. Under physiological conditions, classical monocytes are the most represented sub-population, accounting for around $85 \%$ of total circulating monocytes; the intermediate ones account for around 5\%; and the non-classical ones account for the remaining 10\% [34]. During sepsis, monocytes undergo a shift from classical to intermediate and non-classical forms [35].

Although monocytes have a pivotal role in sepsis, the value of monocyte count for sepsis diagnosis and prognosis is controversial. Some authors reported monocytosis, defined as an increase of monocyte count, while others described monocytopenia associated with increased mortality [32,36]. Thus, the value of monocyte count is limited. Noteworthy, CBC parameters detecting monocytes' alteration, such as monocyte distribution width (MDW) and neutrophil-to-monocyte ratio, have shown promising results, as described above.

\subsubsection{Neutrophils}

Neutrophils represent the most prevalent leukocytes and the most abundant innate cell population in systemic circulation, making up about $40 \%$ to $70 \%$ of the total leukocyte count [37]. They are a key component of the innate immune system and act as sentinels to eliminate invading pathogens.

When infection occurs, neutrophils rapidly migrate to the site of infection and eliminate the invading pathogen by several mechanisms, including phagocytosis and oxidative bursts, neutrophils extracellular traps to execute microbial killing [38].

Under physiological conditions, neutrophils undergo apoptosis to maintain their homeostasis. However, during sepsis, neutrophils undergo several functional alterations, including reduced migration, altered antimicrobial activity, and delayed apoptosis, contributing to immune dysfunction and persistent inflammation [39,40]. Altogether, neutrophil alterations contribute to the worsening of sepsis and the development of secondary complications.

During infection, the neutrophil count increases considerably, and it is generally associated with the overall severity of the infection. However, in severe sepsis, the neutrophil apoptosis is delayed, limiting the usefulness of neutrophil count in some cases. 
Noteworthy, the increase of neutrophils, also known as neutrophilia, can occur in response to a stressor, including physical and emotional stress, as well as smoking [41]. Also, chronic disorders, such as inflammatory bowel disease, rheumatic disease, and hepatitis, as well as congenital disorders, such as Down syndrome, are characterized by baseline neutrophilia [42]. Finally, paraphysiological conditions, such as pregnancy and obesity, could be associated with acute to chronic neutrophilia [43].

Thus, neutrophil count alone has a poor diagnostic and prognostic power for sepsis. Notable, the neutrophil-to-lymphocyte ratio (NLR) has emerged as a reliable sepsis biomarker, as described above.

\subsubsection{Eosinophils}

Eosinophils represent $1-4 \%$ of circulating leukocytes and have a pivotal role in host defence against helminths, the propagation of allergic conditions, and immune and inflammatory networks. They possess receptors for many inflammatory mediators and produce and release an array of biologically active molecules, including cytotoxic proteins, lipid mediators, chemokines, and cytokines. Upon physiological or pathological stimuli, such as infection, eosinophils can migrate into target organs and tissues, where, once activated, they release their products and promote local inflammation, as well as tissue remodeling [44]. Eosinophils are recognized as an important player in modulating local and systemic immune and inflammatory responses.

The reduction of circulating eosinophil count, termed eosinopenia, in response to infection was firstly described in 1893 by Zappert et al. [45]. It is now well known that eosinopenia occurs during acute infection [46].

Abidi et al. firstly evaluated the potential role of eosinopenia as a biomarker of sepsis, showing that it has good sensitivity and specificity in diagnosing sepsis [47]. Then, several authors addressed the value of eosinopenia for diagnosing and predicting the prognosis of sepsis, achieving inconsistence and controversial results [48-51]. Notably, the value of eosinopenia as a criterion of sepsis has been the subject of debate for decades.

A recent meta-analysis by Lin et al., including a total of 3.842 patients, showed that eosinopenia has a high incidence in sepsis, but it is not superior to conventional biomarkers for diagnosing sepsis, such as $C$ reactive protein (CRP) and procalcitonin (PCT) [52]. It should be considered that the studies currently available on the accuracy of eosinopenia as a sepsis biomarker present a high heterogeneity, with sensitivity ranging from 23.2 to $92.5 \%$ and specificity from 28.57 to $91 \%$. However, the authors of the meta-analysis conclude that eosinopenia can still be used in clinical practice for detecting sepsis because it is a simple, convenient, fast, and inexpensive biomarker.

\subsubsection{Basophils}

Basophils represent the rarest granulocytes, making up about $0.5-1 \%$ of the total leukocyte count. They are characterized by the presence of basophilic granules within the cytoplasm, containing several allergic mediators such as histamine, and a high-affinity IgE receptor on the cell surface. The physiological function of basophils has for many years remained enigmatic. Indeed, the study of basophils has long been hampered by both their rarity and the lack of tools for their detection and functional analyses. However, recently developed tools, such as basophil-depleting antibodies and engineered mice deficient for only basophils, shed light on the important role of basophils in allergic responses, protective immunity against parasitic infections and the regulation of the immune system [53]. Specifically, some authors showed that basophils have a role in initiating Th2 cell differentiation by acting as antigen-presenting cells [54,55]. Piliponsky et al. showed that basophils could enhance the innate immune response to bacterial infection and help prevent sepsis in an experimental model [56]. However, only one study explored the role of basophils in patients with sepsis. The authors showed that septic critically ill patients with decreased basophil count at admission to ICU had an increased mortality risk [57]. 


\subsection{Red Blood Cells}

Red blood cells, also termed erythrocytes, are the most abundant circulating cells and are produced within bone marrow through a complex and multi-step process, known as erythropoiesis, which begins with the differentiation of multipotent hematopoietic stem cells into erythroid-committed precursors. The final step leads to the production and release in the bloodstream of reticulocytes, which complete the maturation process into erythrocytes.

Under physiological conditions, RBCs have a characteristic biconcave disc shape, a lifespan of 120 days, and are metabolized by macrophages in the spleen and liver [58]. The best-known function of RBC is the transport and exchange of $\mathrm{O}_{2}$ and $\mathrm{CO}_{2}$ between the lungs and other tissues. However, they also have a pivotal role in cellular blood immunity, representing the main circulating bactericidal cells $[59,60]$.

Sepsis is characterized by decreased RBC count, which could be due to several mechanisms related to the altered production or survival of RBC [61]. The suppression of $\mathrm{RBC}$ production could be the result of functional iron deficiency, decreased erythropoietin synthesis, infection, and inflammation [62]. Moreover, pre-existing clinical conditions, such as cancer, liver disease, or renal impairment as well as new-onset multiple organ dysfunction, particularly of hepatic and renal systems, may contribute to RBC loss during sepsis. Other contributing factors include disseminated intravascular coagulation (DIC), pathogen-associated hemolysis, hypoadrenalism, and nutritional deficiency. In addiction, the volume resuscitation-induced hemodilution is associated with decreased RBC count. Finally, blood loss can also occur by repeated phlebotomy, via the gastrointestinal tract, or from surgical procedures. Withdrawal of blood has been estimated to result in a mean daily loss of 24 to $41 \mathrm{~mL}$ of blood [62].

The shortening of RBC survival could be due to pathogen- and immune-reactioninduced RBC alteration. Indeed, sepsis dramatically alters RBC morphology and rheology (viscosity, aggregation, and deformability). As a consequence, altered RBCs are more rapidly cleared from the circulation through increased uptake by the reticuloendothelial system of the spleen and/or the liver [63]. Overall, reduced RBC count has no diagnostic or prognostic power for sepsis.

Basic CBC provides several parameters related to RBC characteristics, including hemoglobin $(\mathrm{Hb})$, hematocrit, mean cell (or corpuscular) volume (MCV), mean corpuscular hemoglobin $(\mathrm{MCH})$, mean cell hemoglobin concentration $(\mathrm{MCHC})$, and red distribution width (RDW).

\subsubsection{Hemoglobin}

$\mathrm{Hb}$ has a critical role in oxygen delivery to the tissues. Notably, the decrease of hemoglobin, defined as anemia, is common in patients with sepsis and overall in critical illness [64]. It has been estimated that two-thirds of patients admitted to ICU have $\mathrm{Hb}$ levels $<120 \mathrm{~g} / \mathrm{L}$ and that about $40 \%$ have $\mathrm{Hb}<100 \mathrm{~g} / \mathrm{L} ; 97 \%$ of patients develops anemia by day 8 and $100 \%$ by day 13 of ICU hospitalization.

The measurement of $\mathrm{Hb}$ concentration is pivotal for $\mathrm{RBC}$ transfusion decision-making. However, it is always important to evaluate if the benefits of additional oxygen-carrying capacity outweigh the risks. Indeed, in the presence of important organ hypoperfusion, an increased $\mathrm{Hb}$ concentration leading to increased oxygen delivery could exacerbate organ dysfunction and worsen the patients' outcomes. The Surviving Sepsis Campaign 2016 recommends " $R B C$ transfusion should occur only when hemoglobin concentration decreases to $<7.0 \mathrm{~g} / \mathrm{L}$ in adults in the absence of extenuating circumstances, such as myocardial ischemia, severe hypoxemia, or acute hemorrhage" [65].

\subsubsection{Hematocrit}

Hematocrit indicates the fractional volume of a whole blood sample occupied by RBCs, expressed as a percentage. 
Sepsis is characterized by a reduction of hematocrit. The value of hematocrit is used as a target for transfusion [66]. In patients with septic shock, targeting a hematocrit value of $30 \%$ in those with low central venous oxygen saturation during the first $6 \mathrm{~h}$ of resuscitation has been proposed $[67,68]$.

\subsection{3. $\mathrm{MCV}$}

The MCV measures the average size and volume of the circulating RBC. In clinical practice, MCV is a useful index for classifying anemia as microcytic, normocytic or macrocytic. Sepsis is commonly characterized by normocytic anemia. MCV alone does not have a role as a sepsis biomarker. However, the combination of MCV with the standard deviation of erythrocyte volume for calculating RDW has been deeply investigated in patients with sepsis, as described above.

\subsection{4. $\mathrm{MCH}$ and $\mathrm{MCHC}$}

$\mathrm{MCH}$ and MCHC are measures of the hemoglobin content of RBC. MCH indicates the amount of hemoglobin per RBC, while MCHC expresses the amount of hemoglobin per unit volume. To date, the value of $\mathrm{MCH}$ and $\mathrm{MCHC}$ in patients with sepsis has never been explored.

\subsubsection{RDW}

RDW represents a measure of the RBC anisocytosis, defined as the presence of highly heterogeneous RBCs in terms of size and volume [69].

Decreased RDW has no clinical implication, while increased values are indicative of large size variation of RBCs, and, consequently, are clinically meaningful. For a long time, RDW has been regarded as a biomarker for the differential diagnosis of thalassemia and iron-deficiency anemia [70]. In the last decades, a role for RDW in non-hematological disorders, such as autoimmune diseases, cardiovascular diseases, and critical illness, including sepsis, has emerged.

During sepsis, oxidative stress and inflammation, which are features of the sepsis cascade, lead to the reduction of survival and the suppression of the maturation of RBCs, resulting in the release of premature RBCs and consequently, in an increase of RDW [71]. Specifically, on one side, pro-inflammatory cytokines hamper erythropoietin-induced erythrocyte proliferation and maturation; on the other side, oxidative stress reduces RBC survival, producing large premature RBCs. Several authors showed that the rise of RDW $(>15 \%)$ in septic patients is an independent predictor of long- and short-term adverse clinical outcomes, including mortality, especially in the ICU [72-79]. Additionally, Zhao et al. developed a nomogram based on the combination of CBC parameters, including RDW, to predict the risk of mortality in patients with sepsis admitted to the ED [80]. The nomogram, which included increased age, neutrophil-to-lymphocyte ratio (NLR), plateletto-lymphocyte ratio (PLR), and RDW, as well as a decreased lymphocyte-to-monocyte ratio, showed good prognostic accuracy. Additionally, Chen et al. developed a clinical prediction rule, namely the CHARM score, based on clinical and laboratory parameters, including RDW [81]. The CHARM score showed good performance for predicting inhospital mortality in patients with clinically suspected sepsis in the ED.

However, some authors failed to find an association between RDW and outcome in septic patients $[82,83]$.

Overall, most of the evidence supports the role of RDW as an independent prognostic biomarker for sepsis [84].

To date, only a few studies evaluated the accuracy of RDW for diagnosing sepsis [85-87]. Zhang et al. [85] and Laukemann et al. [87] found that RDW was not a reliable biomarker for predicting sepsis. On the other hand, Park et al. showed that septic patients had significantly higher RDW values than healthy controls. Additionally, RDW displayed a high diagnostic accuracy for sepsis prediction. 
Taken together, the literature evidence on the possible role of RDW as a diagnostic biomarker of sepsis is still poor, and further efforts are warranted.

\subsection{Platelets}

Platelets are the smallest elements in the bloodstream. They are anucleate cells produced mainly in the bone marrow by the fragmentation of the megakaryocyte extrusions into the vasculature. Beyond their well-known role in hemostasis, they contribute to the innate immune response to infection and inflammation. Platelets function as sentinels for the rapid detection of microbial invasion and orchestrate a complex intravascular immune defense response that protects against bacterial dissemination [88].

During sepsis, multiple factors, including the direct interaction of the pathogen with DAMP receptors expressed on the platelet surface, coagulation system activation, inflammatory response, and endothelial tissue damage, induce the activation of platelets. Upon activation, platelets exert several functions. Activated platelets rapidly aggregate and express multiple receptors on their surface that further enhance their aggregation with nearby platelets and leukocytes or that directly bind to and sequester extracellular pathogens [89]. Activated platelets also release microbicide molecules and chemokines that facilitate pathogen elimination, signal immune cells, and contribute to inflammation. Finally, platelets promote a pro-inflammatory phenotype of neutrophil $[90,91]$, as well as monocyte, differentiation into macrophages.

The clinical monitoring of platelet count has emerged as a precious tool in the management of septic patients [92]. Indeed, several authors showed that platelet count is a useful diagnostic and prognostic biomarker in sepsis [88]. The reduction of platelet count, termed thrombocytopenia, is a common finding in septic patients, with an incidence ranging from 20 to $70 \%$ across studies [93]. The inclusion of platelet counts as a core parameter for calculating the sepsis-related organ dysfunction score (SOFA); the score emphasizes the importance of such CBC parameters [14]. A low platelet count is strongly correlated with adverse outcomes in sepsis patients, and it is often used for stratifying patients: mild thrombocytopenia (platelet count $<100-150 \times 109 / \mathrm{L}$ ), moderate thrombocytopenia (platelet count between 50 and $100 \times 109 / \mathrm{L}$ ), and severe thrombocytopenia (platelet count $<50 \times 109 / \mathrm{L}$ ), which is associated with worse outcomes [94].

Noteworthy, the kinetic of platelets provides important prognostic information and is more predictive for mortality than a single measurement. The failure of platelet counts to return into the normal range during acute illness is associated with increased mortality, while the recovery of platelet count is associated with survival to ICU discharge. Thus, not only the severity of the thrombocytopenia but especially its persistence is associated with worse outcomes [90].

Sepsis-associated thrombocytopenia is the result of several mechanisms, including the considerable consumption of circulating platelets, which are recruited from the circulation and sequestered within highly vascular organs, such as the lungs and liver; the decreased thrombopoiesis; the hemodilution; the platelet-leukocyte aggregation; the direct pathogeninduced thrombocytopenia; the immune-mediated destruction of platelets; drug-induced thrombocytopenia; DIC; and hemophagocytic lymphohistiocytosis [88,95,96].

Although sepsis is one of the most common causes of thrombocytopenia in critically ill patients, several other causes can mimic sepsis-related thrombocytopenia, such as myelodysplastic syndrome and aplastic anemia, as well as drugs, such as thiazide or chemotherapics, which inhibit platelet production [97].

Not only the platelet count but also platelet-derived indices have been evaluated as biomarkers of sepsis. Platelet indices include the platelet distribution width (PDW), which is a measure of platelet anisocytosis, which, accordingly, increases during accelerated platelet turnover; the mean platelet volume (MPV), which is an indicator of platelet size; and plateletcrit, a measure of total platelet mass. Some authors showed that platelet indices are reliable prognostic biomarkers of sepsis, whereas others found the opposite $[39,96,98]$. 
To date, there are few studies to draw a conclusion on the potential role of platelet indices as biomarkers of sepsis.

\section{CBC Parameters Ratios}

\subsection{Neutrophil-to-Lymphocyte Ratio}

The neutrophil-to-lymphocyte ratio (NLR) is calculated as the neutrophil count divided by the lymphocyte count. During sepsis, neutrophils and lymphocytes rapidly respond to microbial infection in a different manner. Neutrophil count increases dramatically, while the lymphocyte count decreases. Although neutrophil count alone is associated with the overall severity of the infection/inflammation, neutrophil apoptosis is delayed in complicated sepsis cases, suggesting that it has limited prognostic value in some cases [99]. Changes in NLR are indicative of the balance between neutrophil and lymphocyte counts. Several authors showed that NLR is an early biomarker of sepsis, regardless of the source of sepsis, and correlates with sepsis severity scores, such as The Acute Physiology and Chronic Health Evaluation II (APACHE II) score and SOFA score [100-105]. Noteworthy, NLR increases rapidly following infection.

A recent meta-analysis of 14 studies, including 11,564 septic patients, revealed that NLR is a reliable prognostic indicator in patients with sepsis [106]. Specifically, nonsurvivor patients showed significantly higher levels of NLR than survivors. Thus, NLR is an independent predictor of worse outcomes [101]. It seems to be a more reliable sepsis biomarker than either neutrophil count or lymphocyte count alone [107]. When interpreting NLR, it should be kept in mind that its levels can also increase in other conditions, such as hypovolemic shock or exogenous steroid therapy [108].

Overall, increased NLR levels are independently associated with adverse prognosis in septic patients. Unfortunately, several decisional NLR cut-off values have been proposed, ranging from 4.36 to 23.8 [106], independently based on the hematology analyzer used. Thus, before introducing it in clinical practice, a univocal cut-off should be validated.

\subsection{Monocyte-to-Lymphocyte Ratio, Platelet-to-Lymphocyte Ratio, and Mean Platelet Volume-to-Platelet Count}

Literature data regarding the role of monocyte-to-lymphocyte ratio (MLR), platelet-tolymphocyte ratio (PLR), and platelet count-to-mean platelet volume (PC/MPV) in patients with sepsis are scarce. Djordjevic et al. assessed such ratios in patients with sepsis, showing that PC/MPV was higher in non-survivors than survivors, while MLR and PLR did not differ significantly [109]. Similarly, Oh et al. showed that a high PC/MPV ratio (>3.71) was an independent predictor of 28-day mortality [110]. Shen et al. found a strong association between increased PLR and hospital mortality in a large observational study including 5537 sepsis patients [111]. On the other hand, Liberski et al. [98], as well as Ates et al. [112], found that PLR, MLR, and PLT/MPV were not reliable biomarkers for sepsis screening or prognostication. Thus, it is not possible to draw conclusions on the usefulness of these ratios in patients with sepsis and further studies are warranted.

\section{Cell Population Data}

Over the past few decades, hematology analyzers have undergone important technological advancements. The new generation of instruments can generate the so-called cell population data (CPD), which provides quantitative information on the morphological and functional characteristics of blood cells. CPD can be generated by two different technologies, VSC technology and fluorescence flow cytometry.

VSC technology uses direct current impedance for measuring the volume (V) of the cells, a laser beam to measure multiple angled light scatters (S) for evaluating cytoplasmic granularity and the nuclear structure of the cells, and radiofrequency conductivity $(\mathrm{C})$ to analyze the cytoplasmic composition and nuclear volume of the cells [113].

Fluorescence flow cytometry is based on the use of blood-cell membrane surfactant reagents and the fluorescent labeling of cell epitopes followed by flow cytometry analysis. 
Such technology provides information on cell size, internal complexity (granularity), and the content of nucleic acids (DNA and RNA). Briefly, the differential leucocyte count is based on the criteria of granularity (side scatter light), cell size (forward scatter light), and nucleic acid/protein content of cells (fluorescent light intensity). The optical signals of leucocyte differential are presented in the three axes of the white blood cells differential fluorescence (WDF) channel scattergram [113].

CPD parameters provide quantitative values of volume, granularity, and complexity for each cell. The changes in CPD values can provide precious information on the morphological and functional transformation of cells in response to an infection. Thus, several CPD parameters have been evaluated as a biomarker of sepsis. In this section, we describe the most promising CPD parameters for sepsis.

\subsection{Monocyte Distribution Width}

The monocyte distribution width (MDW), also named early sepsis indicator (ESId), represents a measure of the monocytes' anisocytosis. It has been approved by the Food and Drug Administration (FDA) as a biomarker for the early detection of sepsis in ED. Recently, several authors showed that MDW has good diagnostic accuracy for early-identifying patients at high risk of developing sepsis, especially in the ED and the ICU [114-123]. MDW is characterized by a high negative predictive value for sepsis diagnosis. Thus, a value under the decisional cut-off allows the reliable exclusion of the presence of sepsis. In clinical practice, MDW could represent a red flag to identify patients that should undergo further clinical and laboratory evaluations to confirm the suspicion of sepsis. However, further efforts are required before introducing it in clinical practice. Indeed, there is a high heterogeneity among studies on the optimal MDW decisional cut-off value, ranging from 20 to 27 . This could be due to the difference in the study design, the different clinical settings in which the studies were performed (ED, ICU, or the infectious disease unit), the different method of calculations, or the type of anticoagulant used for the blood collection (K3-EDTA vs. K2-EDTA). Specifically, K2-EDTA anticoagulated whole blood samples were associated with lower MDW levels than K3-EDTA. Thus, different cut-off values for K2- or K3-EDTA anticoagulants must be used.

\subsection{Mean Neutrophil Volume and Mean Monocyte Volume}

The mean neutrophil volume (MNV) and mean monocyte volume (MMV) represent the average size of the circulating neutrophil and monocyte populations, respectively. Several authors evaluated the role of MNV and MMV as biomarkers of sepsis, achieving encouraging results [124-127]. Arora et al. [117] found that MNV and MMV were increased in patients with sepsis compared to controls. Additionally, a significant decrease in MNV and MMV values was observed after the initiation of antibiotic therapy. Similarly, Mammen et al. showed that MNV and MMV were increased in patients with sepsis compared to non-septic patients admitted to ICU [126]. Noteworthy, both CPD parameters showed good diagnostic accuracy for sepsis, superior to traditional biomarkers, such as CRP and PCT. The best cut-off for detecting sepsis is 150 and 170 for MNV and MMV, respectively.

Overall, in critically ill patients with suspected sepsis, MNV and MMV may help strengthen the diagnostic probability of sepsis. Further studies to validate the usefulness of such biomarkers are necessary to introduce them in clinical practice.

\subsection{Neutrophil Fluorescence Intensity and Monocyte Internal Structure}

Neutrophil fluorescence intensity (NE-SFL) and monocyte internal structure (MO-X) are two CPD parameters measured by fluorescence flow cytometry technology. Some authors found that both NE-SFL and MO-X have good diagnostic accuracy for diagnosing sepsis and correlate with disease severity [128-130]. 


\subsection{Immature Granulocytes}

Microbial pathogens stimulate the production of cytokines, which induce the release of immature granulocytes (IG) from the bone marrow, including promyelocytes, metamyelocytes, and myelocytes. In the peripheral blood, these immature granulocytes are an indicator of leukopoiesis and can be seen as bands, which are usually referred to as "left shift". The granulocytic shift to the left reflects the active bone marrow response to infection. The band count is commonly obtained by a manual differential count, and, consequently, it is characterized by several drawbacks, such as long TAT; high interobserver variability; and low accuracy, precision and reproducibility. However, these limitations can be overcome by the quantification of IG on the last generation of automated hematology analyzers [131].

Severe sepsis is characterized by a marked increase, up to 10-fold, in neutrophil production by bone marrow and, consequently, by a rise in circulating immature neutrophils. Thus, IG has been assessed as a biomarker for sepsis diagnosis, achieving contradictory results. Some authors found that an elevated value of IG is indicative of sepsis [108], while low values can reliably rule out sepsis [132]. Others reported IG to be nearly worthless [133]. Additionally, a high heterogeneity among studies exists, especially for optimal cut-off value, which ranges from $0.2 \%$ to $3 \%$ [108]. Thus, further studies are required to validate the usefulness of IG for sepsis diagnosis and to identify a univocal cut-off value.

\subsection{Immature Platelet Fraction}

The immature platelet fraction (IPF) is a CPD parameter obtained by flow cytometry technology. It reflects the number of circulating reticulated platelets, which represent the immature platelets and, consequently, provides a direct measure of the platelet production. It increases when platelet production rises and decreases when production falls. A recent systematic review showed that IPF is a reliable biomarker for sepsis diagnosis and prognosis, in terms of severity and mortality [134]. Indeed, it tends to increase before the onset of sepsis and correlates with the scores conventionally used for assessing the severity of sepsis, such as the SOFA score.

\subsection{Delta Neutrophil Index}

The delta neutrophil index (DNI) is an indicator of the circulating immature granulocytes. Some authors showed that DNI has a prognostic value in patients with sepsis. Specifically, increased levels of DNI are associated with mortality [135]. Additionally, Kim et al. found that a value of DNI constantly increased after $72 \mathrm{~h}$ treatment is associated with a worse prognosis [136]. Celik et al. showed that after 6-10 days of effective therapy, patients have normal levels of DNI [137]. Thus, DNI could also be useful for monitoring the efficacy of therapy.

\section{Discussion}

Sepsis is a complex disease, which still represents an open challenge worldwide. The early diagnosis of sepsis combined with appropriate management in the first hour of hospital admission is fundamental for patients with infections, ideally before any signs and symptoms of organ failure have appeared. However, the timely diagnosis of sepsis represents an ongoing challenge for any clinician. Actually, it is based on a combination of clinical and laboratory findings. Among the latter, the gold standard remains the blood culture, but it has several drawbacks, including a long TAT, a high rate of false-negatives, and the vulnerability to pre-analytical variables [138]. Additionally, CRP and PCT are the most common required biomarkers for sepsis diagnosis, prognosis, and therapeutic decision-making [139-143]. Nonetheless, they are characterized by suboptimal diagnostic accuracy, low specificity, modest sensitivity, and high cost, especially for PCT. The attention to the early diagnosis of sepsis has fueled interest in identifying low-cost biomarkers available routinely. In this scenario, $\mathrm{CBC}$ parameters are ideal biomarkers.

They represent early, rapid, inexpensive, and widely available biomarkers, allowing efficient and timely patient management by promptly detecting patients at high risk 
of sepsis, also when the clinician does not suspect it, and by allowing a strengthened monitoring and more aggressive treatment.

The CBC of a patient with sepsis is commonly characterized by lymphocytopenia, neutrophilia, eosinopenia, thrombocytopenia, increased RDW, and increased NLR (Figure 2). The importance of thrombocytopenia in patients with sepsis is emphasized by the inclusion of platelet count in the SOFA score. Moreover, anemia, detected by a reduction of hemoglobin and hematocrit, is a common finding in patients with sepsis. Accordingly, both hematocrit and hemoglobin values are used to guide and monitor blood transfusion therapy. Finally, CPD parameters, which are generated by the new generation analyzers, have been recently evaluated as potential biomarkers of sepsis. Among these, literature data support the usefulness and reliability of MDW and IPF as biomarkers for early sepsis screening and prognosis in acute settings. Although CPD parameters have the great advantage of being available together with basic $\mathrm{CBC}$, they present some important limitations, which hamper their introduction in clinical practice. Indeed, they are not available on all instrumentations, and they depend on the optical design of the analyzer used. Consequently, there is a lack of harmonization among different instruments.

CBC with differential

\begin{tabular}{|c|c|c|c|}
\hline Test & Results & Units & Reference Range \\
\hline WBC count & $20 *$ & $10^{3} / \mu \mathrm{L}$ & $4-11$ \\
\hline Neutrophil & $83.5 *$ & $\%$ & $40-74$ \\
\hline Lymphocytes & 4 * & $\%$ & $20-48$ \\
\hline Monocytes & 8 & $\%$ & $3-11$ \\
\hline Eosinophile & 4 & $\%$ & $0-8$ \\
\hline Basophil & 0.5 & $\%$ & $0-1.5$ \\
\hline Absolute Neutrophil & $16.7 *$ & $10^{3} / \mu \mathrm{L}$ & $2-8$ \\
\hline Absolute Lymphocytes & $0.8 *$ & $10^{3} / \mu \mathrm{L}$ & $1-5$ \\
\hline Absolute Monocytes & $1.6 *$ & $10^{3} / \mu \mathrm{L}$ & $0.16-1$ \\
\hline Absolute Eosinophile & 0.8 & $10^{3} / \mu \mathrm{L}$ & $0.02-0.8$ \\
\hline Absolute Basophil & 0.1 & $10^{3} / \mu \mathrm{L}$ & $0-0.2$ \\
\hline $\mathrm{RBC}$ & $2.8 *$ & $10^{6} / \mu \mathrm{L}$ & $3.8-5$ \\
\hline Hemoglobin & $8.9 *$ & $g / d L$ & $12-16$ \\
\hline Hematocrit & $26.5 *$ & $\%$ & $35-48$ \\
\hline $\mathrm{MCV}$ & 93.7 & $\mathrm{fL}$ & $80-99$ \\
\hline $\mathrm{MCH}$ & 31.3 & $\mathrm{pg}$ & $26-32$ \\
\hline $\mathrm{MCHC}$ & 33.4 & $\mathrm{~g} / \mathrm{dL}$ & $32-36$ \\
\hline RDW & $16 *$ & $\%$ & $11-15$ \\
\hline Absolute RDW & $50 *$ & $\mathrm{fL}$ & $38-48$ \\
\hline $\mathrm{PLT}$ & $70 *$ & $10^{3} / \mu \mathrm{L}$ & $150-450$ \\
\hline
\end{tabular}

Figure 2. The CBC of an adult patient with sepsis. WBC, white blood cells; RBC, red blood cells; $\mathrm{MCV}$, mean cell volume; $\mathrm{MCH}$, mean corpuscular hemoglobin, $\mathrm{MCHC}$, mean cell hemoglobin concentration, RDW, red distribution width; PLT, platelet. * indicates values out of reference range. Notably, reference ranges change according to the instrument used. 
Overall, an alteration of some CBC parameters should be interpreted by clinicians as a warning, which should raise the suspicion of sepsis, that must be always confirmed by more specific laboratory and clinical investigations. Notably, care must be taken when considering $\mathrm{CBC}$ parameters because most of them can be altered in many clinical conditions, and thus, the findings of $\mathrm{CBC}$ must always be considered within the clinical context (Figure 3). The clinical usefulness of CBC parameters is summarized in Table 1.

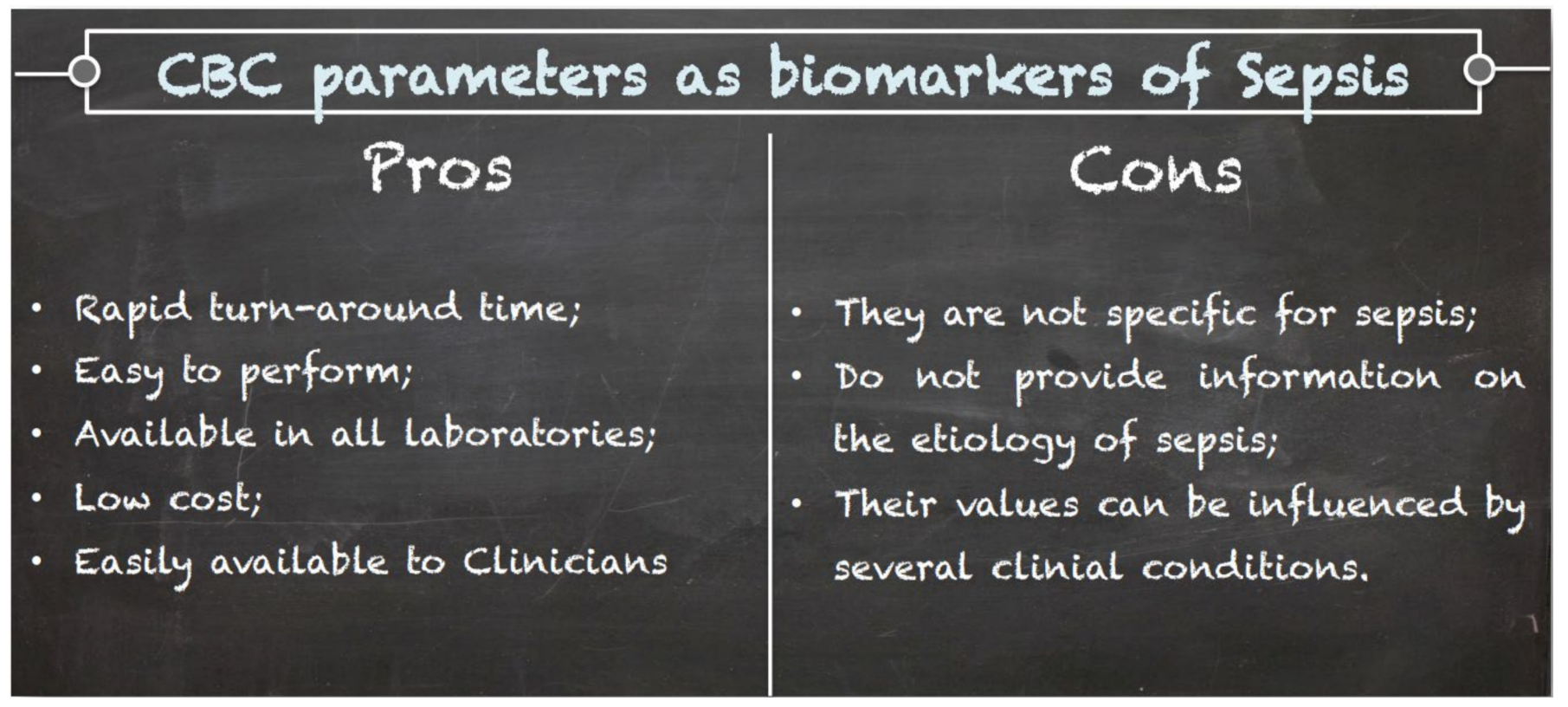

Figure 3. Pros and cons of $\mathrm{CBC}$ parameters as biomarkers of sepsis.

Table 1. Clinical usefulness of CBC parameters for sepsis.

\begin{tabular}{|c|c|c|c|}
\hline & Parameter & Alteration & Clinical Usefulness \\
\hline \multirow{14}{*}{ Basic } & WBC & $\uparrow$ & Diagnosis \\
\hline & Neutrophils & $\uparrow$ & Prognosis \\
\hline & Lymphocytes & $\downarrow$ & Prognosis \\
\hline & Monocytes & $\uparrow \downarrow$ & Controversial \\
\hline & Eosinophil & $\downarrow$ & Diagnosis \\
\hline & Basophil & $\downarrow$ & Prognosis \\
\hline & $\mathrm{RBC}$ & $\downarrow$ & None \\
\hline & Hemoglobin & $\downarrow$ & Guide RBC transfusion \\
\hline & Hematocrit & $\downarrow$ & Target for RBC transfusion \\
\hline & MCV & - & - \\
\hline & $\mathrm{MCH}$ & - & - \\
\hline & $\mathrm{MCHC}$ & - & - \\
\hline & RDW & $\uparrow$ & Prognosis \\
\hline & Platelets & $\downarrow$ & Diagnosis and prognosis \\
\hline \multirow{7}{*}{ CPD } & MDW & $\uparrow$ & Diagnosis \\
\hline & MNV & $\uparrow$ & Diagnosis \\
\hline & MMV & $\uparrow$ & Diagnosis \\
\hline & NE-SFL & $\uparrow$ & Diagnosis and prognosis \\
\hline & MO-X & $\uparrow$ & Diagnosis and prognosis \\
\hline & IPF & $\uparrow$ & Diagnosis and prognosis \\
\hline & DNI & $\uparrow$ & Prognosis and monitoring therapy \\
\hline
\end{tabular}

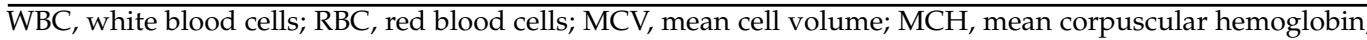
MCHC, mean cell hemoglobin concentration, RDW, red distribution width; MDW, monocyte distribution width; $\mathrm{MNV}$, mean neutrophil volume; MMV, mean monocyte volume; NE-SFL, neutrophil fluorescence intensity; MO-X, monocyte internal structure; IPF, immature platelet function; DNI, delta neutrophil index.

\section{Conclusions}

Global efforts have been made to reduce the burden of sepsis. Predicting sepsis could reduce healthcare costs and save patients' lives by avoiding multi-organ dysfunction pro- 
cesses, reducing ICU admissions, and improving patients' prognoses. To date, the ideal biomarker of sepsis has not been identified, and it is likely that it does not exist because sepsis is a very complex and heterogeneous disease [144]. Thus, a careful and integrated evaluation based on laboratory and clinical findings can help clinicians in its early recognition. CBC parameters detain great potential. Specifically, alteration of CBC parameters could represent an alert for clinicians, which should confirm the suspicion of sepsis with more specific laboratory and clinical investigations. Additionally, CBC parameters could assist clinicians in defining the severity of sepsis and monitoring the therapy.

Author Contributions: Conceptualization, L.A. and M.C.; literature research, R.V.G., C.M.G. and A.I.; writing—original draft preparation, L.A. and A.M.C.; writing—review and editing, B.L.S., G.B. and C.S.; supervision, M.C. All authors have read and agreed to the published version of the manuscript.

Funding: This research received no external funding.

Institutional Review Board Statement: Not applicable.

Informed Consent Statement: Not applicable.

Conflicts of Interest: The authors declare no conflict of interest.

\section{References}

1. Markwart, R.; Saito, H.; Harder, T.; Tomczyk, S.; Cassini, A.; Fleischmann-Struzek, C.; Reichert, F.; Eckmanns, T.; Allegranzi, B. Epidemiology and burden of sepsis acquired in hospitals and intensive care units: A systematic review and meta-analysis. Intensive Care Med. 2020, 46, 1536-1551. [CrossRef] [PubMed]

2. Langley, R.J.; Tsalik, E.L.; van Velkinburgh, J.C.; Glickman, S.W.; Rice, B.J.; Wang, C.; Chen, B.; Carin, L.; Suarez, A.; Mohney, R.P.; et al. An integrated clinico-metabolomic model improves prediction of death in sepsis. Sci. Transl. Med. 2013, 5, 195ra95. [CrossRef] [PubMed]

3. Reinhart, K.; Daniels, R.; Kissoon, N.; Machado, F.R.; Schachter, R.D.; Finfer, S. Recognizing Sepsis as a Global Health Priority-A WHO Resolution. N. Engl. J. Med. 2017, 377, 414-417. [CrossRef] [PubMed]

4. Shashikumar, S.P.; Stanley, M.D.; Sadiq, I.; Li, Q.; Holder, A.; Clifford, G.D.; Nemati, S. Early sepsis detection in critical care patients using multiscale blood pressure and heart rate dynamics. J. Electrocardiol. 2017, 50, 739-743. [CrossRef]

5. Kataria, Y.; Remick, D. Sepsis Biomarkers. Methods Mol. Biol. 2021, 2321, 177-189. [CrossRef]

6. Agnello, L.; Bivona, G.; Parisi, E.; Lucido, G.D.; Iacona, A.; Ciaccio, A.M.; Giglio, R.V.; Ziino, O.; Ciaccio, M. Presepsin and Midregional Proadrenomedullin in Pediatric Oncologic Patients with Febrile Neutropenia. Lab. Med. 2020, 51, 585-591. [CrossRef]

7. Bellia, C.; Agnello, L.; Lo Sasso, B.; Bivona, G.; Raineri, M.S.; Giarratano, A.; Ciaccio, M. Mid-regional pro-adrenomedullin predicts poor outcome in non-selected patients admitted to an intensive care unit. Clin. Chem. Lab. Med. $2019,57,549-555$. [CrossRef]

8. Velissaris, D.; Zareifopoulos, N.; Karamouzos, V.; Karanikolas, E.; Pierrakos, C.; Koniari, I.; Karanikolas, M. Presepsin as a Diagnostic and Prognostic Biomarker in Sepsis. Cureus 2021, 13, e15019. [CrossRef]

9. Funk, D.J.; Parrillo, J.E.; Kumar, A. Sepsis and septic shock: A history. Crit. Care Clin. 2009, 25, 83-101. [CrossRef]

10. Yipp, B.G.; Winston, B.W. Sepsis without SIRS is still sepsis. Ann. Transl. Med. 2015, 3, 294. [CrossRef]

11. Rittirsch, D.; Flierl, M.A.; Ward, P.A. Harmful molecular mechanisms in sepsis. Nat. Rev. Immunol. 2008, 8, 776-787. [CrossRef]

12. Bone, R.C.; Balk, R.A.; Cerra, F.B.; Dellinger, R.P.; Fein, A.M.; Knaus, W.A.; Schein, R.M.; Sibbald, W.J. Definitions for sepsis and organ failure and guidelines for the use of innovative therapies in sepsis. The ACCP/SCCM Consensus Conference Committee. American College of Chest Physicians/Society of Critical Care Medicine. Chest 1992, 101, 1644-1655. [CrossRef]

13. Levy, M.M.; Fink, M.P.; Marshall, J.C.; Abraham, E.; Angus, D.; Cook, D.; Cohen, J.; Opal, S.M.; Vincent, J.L.; Ramsay, G. 2001 SCCM/ESICM/ACCP/ATS/SIS International Sepsis Definitions Conference. Intensive Care Med. 2003, 29, 530-538. [CrossRef] [PubMed]

14. Singer, M.; Deutschman, C.S.; Seymour, C.W.; Shankar-Hari, M.; Annane, D.; Bauer, M.; Bellomo, R.; Bernard, G.R.; Chiche, J.D.; Coopersmith, C.M.; et al. The Third International Consensus Definitions for Sepsis and Septic Shock (Sepsis-3). JAMA 2016, 315, 801-810. [CrossRef]

15. Nedeva, C.; Menassa, J.; Puthalakath, H. Sepsis: Inflammation Is a Necessary Evil. Front. Cell Dev. Biol. 2019, 7, 108. [CrossRef] [PubMed]

16. Brady, J.; Horie, S.; Laffey, J.G. Role of the adaptive immune response in sepsis. Intensive Care Med. Exp. 2020, 8, 20. [CrossRef] [PubMed]

17. Pyo, J.Y.; Park, J.S.; Park, Y.B.; Lee, S.K.; Ha, Y.J.; Lee, S.W. Delta neutrophil index as a marker for differential diagnosis between flare and infection in febrile systemic lupus erythematosus patients. Lupus 2013, 22, 1102-1109. [CrossRef]

18. Pyo, J.Y.; Ha, Y.J.; Song, J.J.; Park, Y.B.; Lee, S.K.; Lee, S.W. Delta neutrophil index contributes to the differential diagnosis between acute gout attack and cellulitis within 24 hours after hospitalization. Rheumatology 2017, 56, 795-801. [CrossRef] [PubMed] 
19. Jarczak, D.; Kluge, S.; Nierhaus, A. Sepsis-Pathophysiology and Therapeutic Concepts. Front. Med. 2021, 8, 628302. [CrossRef] [PubMed]

20. Ayala, A.; Perl, M.; Venet, F.; Lomas-Neira, J.; Swan, R.; Chung, C.S. Apoptosis in sepsis: Mechanisms, clinical impact and potential therapeutic targets. Curr. Pharm. Des. 2008, 14, 1853-1859. [CrossRef]

21. Hotchkiss, R.S.; Swanson, P.E.; Cobb, J.P.; Jacobson, A.; Buchman, T.G.; Karl, I.E. Apoptosis in lymphoid and parenchymal cells during sepsis: Findings in normal and T- and B-cell-deficient mice. Crit. Care Med. 1997, 25, 1298-1307. [CrossRef] [PubMed]

22. Hotchkiss, R.S.; Tinsley, K.W.; Karl, I.E. Role of apoptotic cell death in sepsis. Scand. J. Infect. Dis. 2003, 35, 585-592. [CrossRef] [PubMed]

23. Boomer, J.S.; Shuherk-Shaffer, J.; Hotchkiss, R.S.; Green, J.M. A prospective analysis of lymphocyte phenotype and function over the course of acute sepsis. Crit. Care 2012, 16, R112. [CrossRef] [PubMed]

24. Boomer, J.S.; To, K.; Chang, K.C.; Takasu, O.; Osborne, D.F.; Walton, A.H.; Bricker, T.L.; Jarman, S.D.; Kreisel, D., 2nd; Krupnick, A.S.; et al. Immunosuppression in patients who die of sepsis and multiple organ failure. JAMA 2011, 306, 25942605. [CrossRef] [PubMed]

25. Wesche, D.E.; Lomas-Neira, J.L.; Perl, M.; Chung, C.S.; Ayala, A. Leukocyte apoptosis and its significance in sepsis and shock. J. Leukoc. Biol. 2005, 78, 325-337. [CrossRef]

26. Venet, F.; Davin, F.; Guignant, C.; Larue, A.; Cazalis, M.A.; Darbon, R.; Allombert, C.; Mougin, B.; Malcus, C.; Poitevin-Later, F.; et al. Early assessment of leukocyte alterations at diagnosis of septic shock. Shock 2010, 34, 358-363. [CrossRef]

27. Drewry, A.M.; Samra, N.; Skrupky, L.P.; Fuller, B.M.; Compton, S.M.; Hotchkiss, R.S. Persistent lymphopenia after diagnosis of sepsis predicts mortality. Shock 2014, 42, 383-391. [CrossRef]

28. Chung, K.P.; Chang, H.T.; Lo, S.C.; Chang, L.Y.; Lin, S.Y.; Cheng, A.; Huang, Y.T.; Chen, C.C.; Lee, M.R.; Chen, Y.J.; et al. Severe lymphopenia is associated with elevated plasma interleukin-15 levels and increased mortality during severe sepsis. Shock 2015, 43, 569-575. [CrossRef]

29. Sheikh Motahar Vahedi, H.; Bagheri, A.; Jahanshir, A.; Seyedhosseini, J.; Vahidi, E. Association of Lymphopenia with Short Term Outcomes of Sepsis Patients; A Brief Report. Arch. Acad. Emerg. Med. 2019, 7, e14. [PubMed]

30. Hohlstein, P.; Gussen, H.; Bartneck, M.; Warzecha, K.T.; Roderburg, C.; Buendgens, L.; Trautwein, C.; Koch, A.; Tacke, F. Prognostic Relevance of Altered Lymphocyte Subpopulations in Critical Illness and Sepsis. J. Clin. Med. 2019, 8, 353. [CrossRef]

31. Hortová-Kohoutková, M.; Lázničková, P.; Bendíčková, K.; De Zuani, M.; Andrejčinová, I.; Tomášková, V.; Suk, P.; Šrámek, V.; Helán, M.; Frič, J. Differences in monocyte subsets are associated with short-term survival in patients with septic shock. J. Cell. Mol. Med. 2020, 24, 12504-12512. [CrossRef]

32. Radzyukevich, Y.V.; Kosyakova, N.I.; Prokhorenko, I.R. Participation of Monocyte Subpopulations in Progression of Experimental Endotoxemia (EE) and Systemic Inflammation. J. Immunol. Res. 2021, 2021, 1762584. [CrossRef]

33. Ziegler-Heitbrock, L.; Ancuta, P.; Crowe, S.; Dalod, M.; Grau, V.; Hart, D.N.; Leenen, P.J.; Liu, Y.J.; MacPherson, G.; Randolph, G.J.; et al. Nomenclature of monocytes and dendritic cells in blood. Blood 2010, 116, e74-e80. [CrossRef]

34. Ożańska, A.; Szymczak, D.; Rybka, J. Pattern of human monocyte subpopulations in health and disease. Scand. J. Immunol. 2020, 92, e12883. [CrossRef]

35. Ferreira da Mota, N.V.; Brunialti, M.; Santos, S.S.; Machado, F.R.; Assuncao, M.; Azevedo, L.; Salomao, R. Immunophenotyping of Monocytes During Human Sepsis Shows Impairment in Antigen Presentation: A Shift Toward Nonclassical Differentiation and Upregulation of FC $\gamma$ Ri-Receptor. Shock 2020, 50, 293-300. [CrossRef] [PubMed]

36. Chung, H.; Lee, J.H.; Jo, Y.H.; Hwang, J.E.; Kim, J. Circulating Monocyte Counts and its Impact on Outcomes in Patients With Severe Sepsis Including Septic Shock. Shock 2019, 51, 423-429. [CrossRef] [PubMed]

37. Riley, L.K.; Rupert, J. Evaluation of Patients with Leukocytosis. Am. Fam. Physician 2015, 92, 1004-1011. [PubMed]

38. Witter, A.R.; Okunnu, B.M.; Berg, R.E. The Essential Role of Neutrophils during Infection with the Intracellular Bacterial Pathogen Listeria monocytogenes. J. Immunol. 2016, 197, 1557-1565. [CrossRef]

39. Resende, C.B.; Borges, I.; Gonçalves, W.A.; Carneiro, R.; Rezende, B.M.; Pinho, V.; Nobre, V.; Teixeira, M.M. Neutrophil activity in sepsis: A systematic review. Braz. J. Med. Biol. Res. 2020, 53, e7851. [CrossRef]

40. Gao, L.; Shi, Q.; Li, H.; Guo, Q.; Yan, J.; Zhou, L. Prognostic value of the combined variability of mean platelet volume and neutrophil percentage for short-term clinical outcomes of sepsis patients. Postgrad. Med. 2021, 133, 604-612. [CrossRef]

41. Nakata, A. Psychosocial job stress and immunity: A systematic review. Methods Mol. Biol. 2012, 934, 39-75. [CrossRef] [PubMed]

42. Belok, S.H.; Bosch, N.A.; Klings, E.S.; Walkey, A.J. Evaluation of leukopenia during sepsis as a marker of sepsis-defining organ dysfunction. PLOS ONE 2021, 16, e0252206. [CrossRef] [PubMed]

43. Chandra, S.; Tripathi, A.K.; Mishra, S.; Amzarul, M.; Vaish, A.K. Physiological changes in hematological parameters during pregnancy. Indian J. Hematol. Blood 2012, 28, 144-146. [CrossRef] [PubMed]

44. Nagata, M.; Nakagome, K.; Soma, T. Mechanisms of eosinophilic inflammation. Asia Pac. Allergy 2020, 10, e14. [CrossRef] [PubMed]

45. Zappert, J. Ueber das vorkommen der eosinophilen zellen in menschlichen blute. Z. Klin. Med. 1893, 23, $227-308$.

46. Lavoignet, C.E.; Le Borgne, P.; Chabrier, S.; Bidoire, J.; Slimani, H.; Chevrolet-Lavoignet, J.; Lefebvre, F.; Jebri, R.; Sengler, L.; Bilbault, P. White blood cell count and eosinopenia as valuable tools for the diagnosis of bacterial infections in the ED. Eur. J. Clin. Microbiol. Infect. Dis. 2019, 38, 1523-1532. [CrossRef] 
47. Abidi, K.; Khoudri, I.; Belayachi, J.; Madani, N.; Zekraoui, A.; Zeggwagh, A.A.; Abouqal, R. Eosinopenia is a reliable marker of sepsis on admission to medical intensive care units. Crit. Care 2008, 12, R59. [CrossRef]

48. Shaaban, H.; Daniel, S.; Sison, R.; Slim, J.; Perez, G. Eosinopenia: Is it a good marker of sepsis in comparison to procalcitonin and C-reactive protein levels for patients admitted to a critical care unit in an urban hospital? J. Crit. Care 2010, 25, 570-575. [CrossRef]

49. Anand, D.; Ray, S.; Bhargava, S.; Srivastava, L.M.; Garg, A.; Gafoor, I.; Singh, R.; Dhar, D. Exploration of eosinopenia as a diagnostic parameter to differentiate sepsis from systemic inflammatory response syndrome: Results from an observational study. Indian J. Crit. Care Med. 2016, 20, 285-290. [CrossRef]

50. Tinoco-Sánchez, M.; Suárez-Cuenca, J.A.; Rubio-Guerra, A.F. Usefulness of eosinopenia as prognostic marker of severity in sepsis. Med. Interna Mex. 2017, 33, 572-579.

51. Varghese, J.; Devadas, K.; Cyriac, R.; Vinayakumar, N.; Hareendran, A.; Iqbal, A. Low eosinophil count, a predictor of 28 day mortality in a cohort of cirrhosis patients with sepsis. J. Gastroenterol. Hepatol. 2019, 34, 495.

52. Lin, Y.; Rong, J.; Zhang, Z. Silent existence of eosinopenia in sepsis: A systematic review and meta-analysis. BMC Infect. Dis. 2021, 21, 471. [CrossRef]

53. Karasuyama, H.; Miyake, K.; Yoshikawa, S.; Kawano, Y.; Yamanishi, Y. How do basophils contribute to Th2 cell differentiation and allergic responses? Int. Immunol. 2018, 30, 391-396. [CrossRef]

54. Karasuyama, H.; Obata, K.; Wada, T.; Tsujimura, Y.; Mukai, K. Newly appreciated roles for basophils in allergy and protective immunity. Allergy 2011, 66, 1133-1141. [CrossRef] [PubMed]

55. Olivera, A.; Rivera, J. Paradigm Shifts in Mast Cell and Basophil Biology and Function: An Emerging View of Immune Regulation in Health and Disease. Methods Mol. Biol. 2020, 2163, 3-31. [CrossRef] [PubMed]

56. Piliponsky, A.M.; Shubin, N.J.; Lahiri, A.K.; Truong, P.; Clauson, M.; Niino, K.; Tsuha, A.L.; Nedospasov, S.A.; Karasuyama, H.; Reber, L.L.; et al. Basophil-derived tumor necrosis factor can enhance survival in a sepsis model in mice. Nat. Immunol. 2019, 20, 129-140. [CrossRef] [PubMed]

57. Sinha, H.; Maitra, S.; Anand, R.K.; Aggarwal, R.; Rewari, V.; Subramaniam, R.; Trikha, A.; Arora, M.K.; Batra, R.K.; Saxena, R.; et al. Epidemiology and Prognostic Utility of Cellular Components of Hematological System in Sepsis. Indian J. Crit. Care Med. 2021, 25, 660-667. [CrossRef]

58. Anderson, H.L.; Brodsky, I.E.; Mangalmurti, N.S. The Evolving Erythrocyte: Red Blood Cells as Modulators of Innate Immunity. J. Immunol. 2018, 201, 1343-1351. [CrossRef] [PubMed]

59. Minasyan, H. Erythrocyte and blood antibacterial defense. Eur. J. Microbiol. Immunol. 2014, 4, 138-143. [CrossRef]

60. Minasyan, H. Sepsis: Mechanisms of bacterial injury to the patient. Scand. J. Trauma Resusc. Emerg. Med. 2019, 27, 19. [CrossRef]

61. Effenberger-Neidnicht, K.; Hartmann, M. Mechanisms of Hemolysis During Sepsis. Inflammation 2018, 41, 1569-1581. [CrossRef]

62. Vincent, J.L.; Baron, J.F.; Reinhart, K.; Gattinoni, L.; Thijs, L.; Webb, A.; Meier-Hellmann, A.; Nollet, G.; Peres-Bota, D.; ABC (Anemia and Blood Transfusion in Critical Care) Investigators. Anemia and blood transfusion in critically ill patients. JAMA 2002, 288, 1499-1507. [CrossRef]

63. Bateman, R.M.; Sharpe, M.D.; Singer, M.; Ellis, C.G. The Effect of Sepsis on the Erythrocyte. Int. J. Mol. Sci. 2017, 18, 1932. [CrossRef] [PubMed]

64. Docherty, A.B.; Turgeon, A.F.; Walsh, T.S. Best practice in critical care: Anaemia in acute and critical illness. Transfus. Med. 2018, 28, 181-189. [CrossRef] [PubMed]

65. Rhodes, A.; Evans, L.E.; Alhazzani, W.; Levy, M.M.; Antonelli, M.; Ferrer, R.; Kumar, A.; Sevransky, J.E.; Sprung, C.L.; Nunnally, M.E.; et al. Surviving Sepsis Campaign: International Guidelines for Management of Sepsis and Septic Shock: 2016. Intensive Care Med. 2017, 43, 304-377. [CrossRef]

66. Van Beest, P.A.; Hofstra, J.J.; Schultz, M.J.; Boerma, E.C.; Spronk, P.E.; Kuiper, M.A. The incidence of low venous oxygen saturation on admission to the intensive care unit: A multi-center observational study in The Netherlands. Crit. Care 2008, 12, R33. [CrossRef]

67. Cable, C.A.; Razavi, S.A.; Roback, J.D.; Murphy, D.J. RBC Transfusion Strategies in the ICU: A Concise Review. Crit. Care Med. 2019, 47, 1637-1644. [CrossRef] [PubMed]

68. Yealy, D.M.; Kellum, J.A.; Huang, D.T.; Barnato, A.E.; Weissfeld, L.A.; Pike, F.; Terndrup, T.; Wang, H.E.; Hou, P.C.; LoVecchio, F.; et al. A randomized trial of protocol-based care for early septic shock. N. Engl. J. Med. 2014, 370, 1683-1693. [CrossRef]

69. Lippi, G.; Cervellin, G.; Sanchis-Gomar, F. Red blood cell distribution width: A marker of anisocytosis potentially associated with atrial fibrillation. World J. Cardiol. 2019, 11, 292-304. [CrossRef]

70. Salvagno, G.L.; Sanchis-Gomar, F.; Picanza, A.; Lippi, G. Red blood cell distribution width: A simple parameter with multiple clinical applications. Crit. Rev. Clin. Lab. Sci. 2015, 52, 86-105. [CrossRef]

71. Krishna, V.; Pillai, G.; Velickakathu Sukumaran, S. Red Cell Distribution Width As a Predictor of Mortality in Patients With Sepsis Cureus 2021, 13, e12912. [CrossRef] [PubMed]

72. Huda, A.Q.; Karim, M.R.; Mahmud, M.A.; Islam, M.S.; Haque, M.F.; Islam, M.R.; Hossain, M.A. Use of Acute Physiology and Chronic Health Evaluation (APACHE)-II and Red Cell Distribution Width (RDW) for Assessment of Mortality of Patients with Sepsis in ICU. Mymensingh Med. J. 2017, 26, 585-591. [PubMed]

73. Li, Y.; She, Y.; Fu, L.; Zhou, R.; Xiang, W.; Luo, L. Association Between Red Cell Distribution Width and Hospital Mortality in Patients with Sepsis. J. Int. Med. Res. 2021, 49, 3000605211004221. [CrossRef] [PubMed] 
74. Fan, Y.W.; Liu, D.; Chen, J.M.; Li, W.J.; Gao, C.J. Fluctuation in red cell distribution width predicts disseminated intravascular coagulation morbidity and mortality in sepsis: A retrospective single-center study. Minerva Anestesiol. 2021, 87, 52-64. [CrossRef]

75. Jo, Y.H.; Kim, K.; Lee, J.H.; Kang, C.; Kim, T.; Park, H.M.; Kang, K.W.; Kim, J.; Rhee, J.E. Red cell distribution width is a prognostic factor in severe sepsis and septic shock. Am. J. Emerg. Med. 2013, 31, 545-548. [CrossRef]

76. Kim, C.H.; Park, J.T.; Kim, E.J.; Han, J.H.; Han, J.S.; Choi, J.Y.; Han, S.H.; Yoo, T.H.; Kim, Y.S.; Kang, S.W.; et al. An increase in red blood cell distribution width from baseline predicts mortality in patients with severe sepsis or septic shock. Crit. Care 2013, 17, R282. [CrossRef]

77. Han, Y.Q.; Zhang, L.; Yan, L.; Li, P.; Ouyang, P.H.; Lippi, G.; Hu, Z.D. Red blood cell distribution width predicts long-term outcomes in sepsis patients admitted to the intensive care unit. Clin. Chim. Acta 2018, 487, 112-116. [CrossRef] [PubMed]

78. Lorente, L.; Martín, M.M.; Abreu-González, P.; Solé-Violán, J.; Ferreres, J.; Labarta, L.; Díaz, C.; González, O.; García, D.; Jiménez, A.; et al. Red blood cell distribution width during the first week is associated with severity and mortality in septic patients. PLoS ONE 2014, 9, e105436. [CrossRef]

79. Özdoğan, H.K.; Karateke, F.; Özyazıcı, S.; Özdoğan, M.; Özaltun, P.; Kuvvetli, A.; Gökler, C.; Ersoy, Z. The predictive value of red cell distribution width levels on mortality in intensive care patients with community-acquired intra-abdominal sepsis. Ulusal Travma ve Acil Cerrahi Dergisi 2015, 21, 352-357. [CrossRef]

80. Zhao, C.; Wei, Y.; Chen, D.; Jin, J.; Chen, H. Prognostic value of an inflammatory biomarker-based clinical algorithm in septic patients in the emergency department: An observational study. Int. Immunopharmacol. 2020, 80, 106145. [CrossRef]

81. Chen, K.F.; Liu, S.H.; Li, C.H.; Wu, C.C.; Chaou, C.H.; Tzeng, I.S.; Hsieh, Y.H.; Blaney, G.N.; Liu, Z.Y.; Han, S.T.; et al. Development and validation of a parsimonious and pragmatic CHARM score to predict mortality in patients with suspected sepsis. Am. J. Emerg. Med. 2017, 35, 640-646. [CrossRef]

82. Fontana, V.; Spadaro, S.; Bond, O.; Cavicchi, F.Z.; Annoni, F.; Donadello, K.; Vincent, J.L.; De Backer, D.; Taccone, F.S. No relationship between red blood cell distribution width and microcirculatory alterations in septic patients. Clin. Hemorheol. Microcirc. 2017, 66, 131-141. [CrossRef] [PubMed]

83. Ghimire, R.; Shakya, Y.M.; Shrestha, T.M.; Neupane, R.P. The utility of red cell distribution width to predict mortality of septic patients in a tertiary hospital of Nepal. BMC Emerg. Med. 2020, 20, 43. [CrossRef] [PubMed]

84. Hu, Z.D.; Lippi, G.; Montagnana, M. Diagnostic and prognostic value of red blood cell distribution width in sepsis: A narrative review. Clin. Biochem. 2020, 77, 1-6. [CrossRef] [PubMed]

85. Zhang, H.B.; Chen, J.; Lan, Q.F.; Ma, X.J.; Zhang, S.Y. Diagnostic values of red cell distribution width, platelet distribution width and neutrophil-lymphocyte count ratio for sepsis. Exp. Ther. Med. 2016, 12, 2215-2219. [CrossRef]

86. Park, S.H.; Park, C.J.; Lee, B.R.; Nam, K.S.; Kim, M.J.; Han, M.Y.; Kim, Y.J.; Cho, Y.U.; Jang, S. Sepsis affects most routine and cell population data (CPD) obtained using the Sysmex XN-2000 blood cell analyzer: Neutrophil-related CPD NE-SFL and NE-WY provide useful information for detecting sepsis. Int. J. Lab. Hematol. 2015, 37, 190-198. [CrossRef]

87. Laukemann, S.; Kasper, N.; Kulkarni, P.; Steiner, D.; Rast, A.C.; Kutz, A.; Felder, S.; Haubitz, S.; Faessler, L.; Huber, A.; et al. Can We Reduce Negative Blood Cultures With Clinical Scores and Blood Markers? Results From an Observational Cohort Study. Medicine 2015, 94, e2264. [CrossRef]

88. McDonald, B.; Dunbar, M. Platelets and Intravascular Immunity: Guardians of the Vascular Space During Bloodstream Infections and Sepsis. Front. Immunol. 2019, 10, 2400. [CrossRef]

89. Guo, L.; Rondina, M.T. The Era of Thromboinflammation: Platelets Are Dynamic Sensors and Effector Cells During Infectious Diseases. Front. Immunol. 2019, 10, 2204. [CrossRef]

90. Assinger, A.; Schrottmaier, W.C.; Salzmann, M.; Rayes, J. Platelets in Sepsis: An Update on Experimental Models and Clinical Data. Front. Immunol. 2019, 10, 1687. [CrossRef]

91. Ma, A.C.; Kubes, P. Platelets, neutrophils, and neutrophil extracellular traps (NETs) in sepsis. J. Thromb. Haemost. 2008, 6, 415-420. [CrossRef]

92. Dewitte, A.; Lepreux, S.; Villeneuve, J.; Rigothier, C.; Combe, C.; Ouattara, A.; Ripoche, J. Blood platelets and sepsis pathophysiology: A new therapeutic prospect in critically [corrected] ill patients? Ann. Intensive Care 2017, 7, 115. [CrossRef]

93. Levi, M. Platelets in Critical Illness. Semin. Thromb. Hemost. 2016, 42, 252-257. [CrossRef] [PubMed]

94. Claushuis, T.A.; van Vught, L.A.; Scicluna, B.P.; Wiewel, M.A.; Klein Klouwenberg, P.M.; Hoogendijk, A.J.; Ong, D.S.; Cremer, O.L.; Horn, J.; Franitza, M.; et al. Thrombocytopenia is associated with a dysregulated host response in critically ill sepsis patients. Blood 2016, 127, 3062-3072. [CrossRef] [PubMed]

95. Vardon-Bounes, F.; Gratacap, M.P.; Groyer, S.; Ruiz, S.; Georges, B.; Seguin, T.; Garcia, C.; Payrastre, B.; Conil, J.M.; Minville, V. Kinetics of mean platelet volume predicts mortality in patients with septic shock. PLoS ONE 2019, 14, e0223553. [CrossRef] [PubMed]

96. Vardon-Bounes, F.; Ruiz, S.; Gratacap, M.P.; Garcia, C.; Payrastre, B.; Minville, V. Platelets Are Critical Key Players in Sepsis. Int. J. Mol. Sci. 2019, 20, 3494. [CrossRef]

97. Giustozzi, M.; Ehrlinder, H.; Bongiovanni, D.; Borovac, J.A.; Guerreiro, R.A.; Gąsecka, A.; Papakonstantinou, P.E.; Parker, W. Coagulopathy and sepsis: Pathophysiology, clinical manifestations and treatment. Blood Rev. 2021, 100864, in press. [CrossRef] [PubMed]

98. Liberski, P.S.; Szewczyk, M.; Krzych, Ł.J. Haemogram-Derived Indices for Screening and Prognostication in Critically Ill Septic Shock Patients: A Case-Control Study. Diagnostics 2020, 10, 638. [CrossRef] 
99. Taneja, R.; Parodo, J.; Jia, S.H.; Kapus, A.; Rotstein, O.D.; Marshall, J.C. Delayed neutrophil apoptosis in sepsis is associated with maintenance of mitochondrial transmembrane potential and reduced caspase-9 activity. Crit. Care Med. 2004, 32, 1460-1469. [CrossRef]

100. Rehman, F.U.; Khan, A.; Aziz, A.; Iqbal, M.; Mahmood, S.; Ali, N. Neutrophils to Lymphocyte Ratio: Earliest and Efficacious Markers of Sepsis. Cureus 2020, 12, e10851. [CrossRef]

101. Meshaal, M.S.; Nagi, A.; Eldamaty, A.; Elnaggar, W.; Gaber, M.; Rizk, H. Neutrophil-to-lymphocyte ratio (NLR) and plateletto-lymphocyte ratio (PLR) as independent predictors of outcome in infective endocarditis (IE). Egypt Heart J. 2019, 71, 13. [CrossRef]

102. Can, E.; Hamilcikan, S..; Can, C. The Value of Neutrophil to Lymphocyte Ratio and Platelet to Lymphocyte Ratio for Detecting Early-onset Neonatal Sepsis. J. Pediatr. Hematol. Oncol. 2018, 40, e229-e232. [CrossRef]

103. De Jager, C.P.; Wever, P.C.; Gemen, E.F.; Kusters, R.; van Gageldonk-Lafeber, A.B.; van der Poll, T.; Laheij, R.J. The neutrophillymphocyte count ratio in patients with community-acquired pneumonia. PLoS ONE 2012, 7, e46561. [CrossRef]

104. Dursun, A.; Ozsoylu, S.; Akyildiz, B.N. Neutrophil-to-lymphocyte ratio and mean platelet volume can be useful markers to predict sepsis in children. Pak. J. Med. Sci. 2018, 34, 918-922. [CrossRef]

105. Velissaris, D.; Pantzaris, N.D.; Bountouris, P.; Gogos, C. Correlation between neutrophil-to-lymphocyte ratio and severity scores in septic patients upon hospital admission. A series of 50 patients. Rom. J. Intern. Med. 2018, 56, 153-157. [CrossRef] [PubMed]

106. Huang, Z.; Fu, Z.; Huang, W.; Huang, K. Prognostic value of neutrophil-to-lymphocyte ratio in sepsis: A meta-analysis. Am. J. Emerg. Med. 2020, 38, 641-647. [CrossRef] [PubMed]

107. Kumarasamy, C.; Sabarimurugan, S.; Madurantakam, R.M.; Lakhotiya, K.; Samiappan, S.; Baxi, S.; Nachimuthu, R.; Gothandam, K.M.; Jayaraj, R. Prognostic significance of blood inflammatory biomarkers NLR, PLR, and LMR in cancer-A protocol for systematic review and meta-analysis. Medicine 2019, 98, e14834. [CrossRef]

108. Farkas, J.D. The complete blood count to diagnose septic shock. J. Thorac. Dis. 2020, 12, S16-S21. [CrossRef]

109. Djordjevic, D.; Rondovic, G.; Surbatovic, M.; Stanojevic, I.; Udovicic, I.; Andjelic, T.; Zeba, S.; Milosavljevic, S.; Stankovic, N.; Abazovic, D.; et al. Neutrophil-to-Lymphocyte Ratio, Monocyte-to-Lymphocyte Ratio, Platelet-to-Lymphocyte Ratio, and Mean Platelet Volume-to-Platelet Count Ratio as Biomarkers in Critically Ill and Injured Patients: Which Ratio to Choose to Predict Outcome and Nature of Bacteremia? Mediat. Inflamm. 2018, 2018, 3758068. [CrossRef]

110. Oh, G.H.; Chung, S.P.; Park, Y.S.; Hong, J.H.; Lee, H.S.; Chung, H.S.; You, J.S.; Park, J.W.; Park, I. Mean Platelet Volume to Platelet Count Ratio as a Promising Predictor of Early Mortality in Severe Sepsis. Shock 2017, 47, 323-330. [CrossRef] [PubMed]

111. Shen, Y.; Huang, X.; Zhang, W. Platelet-to-lymphocyte ratio as a prognostic predictor of mortality for sepsis: Interaction effect with disease severity-A retrospective study. BMJ Open 2019, 9, e022896. [CrossRef] [PubMed]

112. Ates, S.; Oksuz, H.; Dogu, B.; Bozkus, F.; Ucmak, H.; Yanit, F. Can mean platelet volume and mean platelet volume/platelet count ratio be used as a diagnostic marker for sepsis and systemic inflammatory response syndrome? Saudi Med. J. 2015, 36, 1186-1190. [CrossRef] [PubMed]

113. Urrechaga, E.; Bóveda, O.; Aguirre, U. Improvement in detecting sepsis using leukocyte cell population data (CPD). Clin. Chem. Lab. Med. 2019, 57, 918-926. [CrossRef]

114. Hausfater, P.; Robert Boter, N.; Morales Indiano, C.; Cancella de Abreu, M.; Marin, A.M.; Pernet, J.; Quesada, D.; Castro, I.; Careaga, D.; Arock, M.; et al. Monocyte distribution width (MDW) performance as an early sepsis indicator in the emergency department: Comparison with CRP and procalcitonin in a multicenter international European prospective study. Crit. Care 2021, 25, 227. [CrossRef] [PubMed]

115. Piva, E.; Zuin, J.; Pelloso, M.; Tosato, F.; Fogar, P.; Plebani, M. Monocyte distribution width (MDW) parameter as a sepsis indicator in intensive care units. Clin. Chem. Lab. Med. 2021, 59, 1307-1314. [CrossRef]

116. Woo, A.; Oh, D.K.; Park, C.J.; Hong, S.B. Monocyte distribution width compared with C-reactive protein and procalcitonin for early sepsis detection in the emergency department. PLOS ONE 2021, 16, e0250101. [CrossRef]

117. Agnello, L.; Bivona, G.; Vidali, M.; Scazzone, C.; Giglio, R.V.; Iacolino, G.; Iacona, A.; Mancuso, S.; Ciaccio, A.M.; Lo Sasso, B.; et al. Monocyte distribution width (MDW) as a screening tool for sepsis in the Emergency Department. Clin. Chem. Lab. Med. 2020, 58, 1951-1957. [CrossRef]

118. Agnello, L.; Iacona, A.; Lo Sasso, B.; Scazzone, C.; Pantuso, M.; Giglio, R.V.; Gambino, C.M.; Ciaccio, A.M.; Bivona, G.; Vidali, M.; et al. A new tool for sepsis screening in the Emergency Department. Clin. Chem. Lab. Med. 2021, 59, $1600-1605$. [CrossRef]

119. Agnello, L.; Iacona, A.; Maestri, S.; Lo Sasso, B.; Giglio, R.V.; Mancuso, S.; Ciaccio, A.M.; Vidali, M.; Ciaccio, M. Independent Validation of Sepsis Index for Sepsis Screening in the Emergency Department. Diagnostics 2021, 11, 1292. [CrossRef] [PubMed]

120. Agnello, L.; Lo Sasso, B.; Vidali, M.; Scazzone, C.; Gambino, C.M.; Giglio, R.V.; Ciaccio, A.M.; Bivona, G.; Ciaccio, M. Validation of monocyte distribution width decisional cutoff for sepsis detection in the acute setting. Int. J. Lab. Hematol. 2021, 43, O183-O185. [CrossRef]

121. Agnello, L.; Sasso, B.L.; Giglio, R.V.; Bivona, G.; Gambino, C.M.; Cortegiani, A.; Ciaccio, A.M.; Vidali, M.; Ciaccio, M. Monocyte distribution width as a biomarker of sepsis in the intensive care unit: A pilot study. Ann. Clin. Biochem. 2021, 58, 70-73. [CrossRef]

122. Crouser, E.D.; Parrillo, J.E.; Martin, G.S.; Huang, D.T.; Hausfater, P.; Grigorov, I.; Careaga, D.; Osborn, T.; Hasan, M.; Tejidor, L. Monocyte distribution width enhances early sepsis detection in the emergency department beyond SIRS and qSOFA. J. Intensive Care 2020, 8, 33. [CrossRef] [PubMed] 
123. Crouser, E.D.; Parrillo, J.E.; Seymour, C.; Angus, D.C.; Bicking, K.; Tejidor, L.; Magari, R.; Careaga, D.; Williams, J.; Closser, D.R.; et al. Improved Early Detection of Sepsis in the ED With a Novel Monocyte Distribution Width Biomarker. Chest 2017, 152, 518-526. [CrossRef] [PubMed]

124. Arora, P.; Gupta, P.K.; Lingaiah, R.; Mukhopadhyay, A.K. Volume, conductivity, and scatter parameters of leukocytes as early markers of sepsis and treatment response. J. Lab. Physicians 2019, 11, 29-33. [CrossRef] [PubMed]

125. Mardi, D.; Fwity, B.; Lobmann, R.; Ambrosch, A. Mean cell volume of neutrophils and monocytes compared with C-reactive protein, interleukin- 6 and white blood cell count for prediction of sepsis and nonsystemic bacterial infections. Int. J. Lab. Hematol. 2010, 32, 410-418. [CrossRef] [PubMed]

126. Mammen, J.; Choudhuri, J.; Paul, J.; Sudarsan, T.I.; Josephine, T.; Mahasampath, G.; Jeyaseelan, V.; Nair, S.C.; Peter, J.V. Cytomorphometric Neutrophil and Monocyte Markers May Strengthen the Diagnosis of Sepsis. J. Intensive Care Med. 2018, 33, 656-662. [CrossRef]

127. Lee, A.J.; Kim, S.G. Mean cell volumes of neutrophils and monocytes are promising markers of sepsis in elderly patients. Blood Res. 2013, 48, 193-197. [CrossRef]

128. Buoro, S.; Seghezzi, M.; Vavassori, M.; Dominoni, P.; Apassiti Esposito, S.; Manenti, B.; Mecca, T.; Marchesi, G.; Castellucci, E.; Azzarà, G.; et al. Clinical significance of cell population data (CPD) on Sysmex XN-9000 in septic patients with our without liver impairment. Ann. Transl. Med. 2016, 4, 418. [CrossRef]

129. Urrechaga, E.; Bóveda, O.; Aguirre, U. Role of leucocytes cell population data in the early detection of sepsis. J. Clin. Pathol. 2018, 71, 259-266. [CrossRef]

130. Urrechaga, E. Reviewing the value of leukocytes cell population data (CPD) in the management of sepsis. Ann. Transl. Med. 2020, 8, 953. [CrossRef]

131. Park, D.H.; Park, K.; Park, J.; Park, H.H.; Chae, H.; Lim, J.; Oh, E.J.; Kim, Y.; Park, Y.J.; Han, K. Screening of sepsis using leukocyte cell population data from the Coulter automatic blood cell analyzer DxH800. Int. J. Lab. Hematol. 2011, 33, 391-399. [CrossRef]

132. Ayres, L.S.; Sgnaolin, V.; Munhoz, T.P. Immature granulocytes index as early marker of sepsis. Int. J. Lab. Hematol. 2019, 41, 392-396. [CrossRef] [PubMed]

133. Karon, B.S.; Tolan, N.V.; Wockenfus, A.M.; Block, D.R.; Baumann, N.A.; Bryant, S.C.; Clements, C.M. Evaluation of lactate, white blood cell count, neutrophil count, procalcitonin and immature granulocyte count as biomarkers for sepsis in emergency department patients. Clin. Biochem. 2017, 50, 956-958. [CrossRef] [PubMed]

134. Tauseef, A.; Zafar, M.; Arshad, W.; Thirumalareddy, J.; Sood, A.; Farooque, U.; Nair, S.; Mirza, M. Role of immature platelet fraction (IPF) in sepsis patients: A systematic review. J. Fam. Med. Prim. Care 2021, 10, 2148-2152. [CrossRef]

135. Ahn, C.; Kim, W.; Lim, T.H.; Cho, Y.; Choi, K.S.; Jang, B.H. The delta neutrophil index (DNI) as a prognostic marker for mortality in adults with sepsis: A systematic review and meta-analysis. Sci. Rep. 2018, 8, 6621. [CrossRef] [PubMed]

136. Kim, H.W.; Yoon, J.H.; Jin, S.J.; Kim, S.B.; Ku, N.S.; Jeong, S.J.; Han, S.H.; Choi, J.Y.; Kim, J.M.; Song, Y.G. Delta neutrophil index as a prognostic marker of early mortality in gram negative bacteremia. Infect. Chemother. 2014, 46, 94-102. [CrossRef]

137. Celik, I.H.; Arifoglu, I.; Arslan, Z.; Aksu, G.; Bas, A.Y.; Demirel, N. The value of delta neutrophil index in neonatal sepsis diagnosis, follow-up and mortality prediction. Early Hum. Dev. 2019, 131, 6-9. [CrossRef]

138. Riedel, S.; Carroll, K.C. Early Identification and Treatment of Pathogens in Sepsis: Molecular Diagnostics and Antibiotic Choice. Clin. Chest Med. 2016, 37, 191-207. [CrossRef]

139. Agnello, L.; Bellia, C.; Di Gangi, M.; Lo Sasso, B.; Calvaruso, L.; Bivona, G.; Scazzone, C.; Dones, P.; Ciaccio, M. Utility of serum procalcitonin and C-reactive protein in severity assessment of community-acquired pneumonia in children. Clin. Biochem. 2016, 49, 47-50. [CrossRef]

140. Giulia, B.; Luisa, A.; Concetta, S.; Bruna, L.S.; Chiara, B.; Marcello, C. Procalcitonin and community-acquired pneumonia (CAP) in children. Clin. Chim. Acta 2015, 451, 215-218. [CrossRef]

141. Covington, E.W.; Roberts, M.Z.; Dong, J. Procalcitonin Monitoring as a Guide for Antimicrobial Therapy: A Review of Current Literature. Pharmacotherapy 2018, 38, 569-581. [CrossRef] [PubMed]

142. Malik, M.; Sreekantan Nair, A.; Illango, J.; Siddiqui, N.; Gor, R.; Fernando, R.W.; Hamid, P. The Advancement in Detecting Sepsis and Its Outcome: Usefulness of Procalcitonin in Diagnosing Sepsis and Predicting Fatal Outcomes in Patients Admitted to Intensive Care Unit. Cureus 2021, 13, e14439. [CrossRef] [PubMed]

143. Ciaccio, M.; Lo Sasso, B.; Scazzone, C.; Gambino, C.M.; Ciaccio, A.M.; Bivona, G.; Piccoli, T.; Giglio, R.V.; Agnello, L. COVID-19 and Alzheimer's Disease. Brain Sci. 2021, 11, 305. [CrossRef]

144. Lippi, G. Sepsis biomarkers: Past, present and future. Clin. Chem. Lab. Med. 2019, 57, 1281-1283. [CrossRef] [PubMed] 